\title{
Higher Education Management System Based on Principles of Strategic Development
}

\author{
Tetiana V. Cherepovska \\ Stepan Gzhytskyi National University of Veterinary Medicine and Biotechnologies Lviv \\ Ivan O. Parubchak \\ Stepan Gzhytskyi National University of Veterinary Medicine and Biotechnologies Lviv \\ Dmytro V. Karamyshev \\ Kharkiv Regional Institute of Public Administration of the National Academy for Public \\ Administration Under the President of Ukraine
}

The aim of the article was to investigate the problems of formation and effective functioning of the higher education management system on the basis of strategic development. As a research method, the analysis of the interrelations of such components of the system as element, component, subsystem and supersystem in relation to the management system of higher education in Ukraine was used. It was concluded that at the exit from the developed system, alternative options should be obtained for developing a higher education management strategy, in which the central link will be the search for optimal, scientific-based practical management solutions for the constant improvement and self-organizing of the developed system. Overall, it was concluded that the system should be implemented in real-time with the help of comprehensive planned measures aimed at increasing, coordinating, and effective use of the system components based on the system approach taking into account the characteristics of the internal and external environment and other factors of influence.

Keywords: public governance, public management, system approach, strategy

\section{INTRODUCTION}

The modern development of the domestic educational and scientific system takes place in fundamentally new conditions of ongoing market transformations, which create conditions for the growth of mobility, globalization, increased competition, and unification of these systems. Categories and processes, innovations of the modern world, represented in both international and national legislation, form the conceptual framework of the education system and require a deeper multilateral understanding and clear structuring. Among the main challenges to the development of the higher education system in Ukraine are the improvement of higher education management processes and systems (including through decentralization, deregulation, the involvement of public and social management, and innovative 
transformations in financing mechanisms), the provision and expansion of autonomy, increased responsibility and quality of educational services of higher education institutions.

Thus, the problem of forming and improving the higher education management system of Ukraine at the strategic level is due to the strengthening of the world and domestic challenges faced by global and national economies; the increasing level of influence of the world labor market and educational services, threats and risks that have arisen for the Ukrainian economy in recent decades; the development of innovative techniques and new generation technologies; worsening of social and demographic problems, etc.

The problem of effective state and public management of higher education in the country was dealt with by many well-known scientists, namely: L.V. Holovii, I. Vakarchuk, M.V. Klov, T.O. Karabin, L.P. Oderii, M.V. Dmytryshyn, O.M. Antonova, T.A. Yashchuk, R.V. Voloshchuk, Y. Romanenko, O. Nepomnyashchyy, A.P. Lelechenko, O.I. Lebedinska, T.M. Derun, O.V. Berdanova, O.A. Diegtiar, S.S. Rezk, V.F. Obolentsev, T.A. Yashchuk and others. The research carried out by these scientists made it possible to form the basic conditions for the quality of the higher education management system. But, it should be noted that a unified effective and universal higher education management system of Ukraine within the framework of strategic development has not yet been formed

The purpose of the article is to form and improve the higher education management system, taking into account its strategic orientation. To achieve the purpose, the article addresses the following objectives:

- to identify key study guidelines within the framework of a systematic approach;

- to systematize the components of the higher education management system and investigate their interrelationship;

- to develop a system for the higher education management system in Ukraine within the framework of strategic development and describe its elements;

- to form strategic directions for the development of the higher education management system of Ukraine and operational tasks for managers to fulfill them.

In the modern era of economic and social transformation, which is taking place in all spheres of life of Ukrainian society, the problem of improving the basic mechanisms for the functioning of the scientific and educational field as a necessary basis and resource for the development and formation of personnel, scientific, technical and cultural potential of Ukraine becomes particularly urgent.

So, constant dynamic changes in all spheres of activity in Ukrainian society are impossible without taking into account a systematic approach to reforming the Ukrainian education system. At the same time, these changes should be consistent with European and world trends in the development of national educational systems. The priority of the development of education and the need for strategic reform of the higher education system is fully reflected in the main documents regulating the educational activities of Ukraine. In the general sense, it is determined that education is a crucial factor in the socio-economic, political, cultural, and scientific activities of the society, a strategic resource for increasing the well-being of citizens, ensuring national interests, strengthening the authority and competitiveness of the state in the international arena.

\section{CHARACTERISTICS OF HIGHER EDUCATION SYSTEM IN UKRAINE: ANALYSES}

According to the Law of Ukraine "On Higher Education" the concept of "higher education" is "a combination of systematic knowledge, competencies and practical skills, ways of thinking, professional, attitudinal and civic qualities, moral and ethical values, and other competencies obtained at a higher educational institution (scientific institution) in a particular area of knowledge on certain qualifications at higher education levels, which are more complex than the level of complete general secondary education". It should be noted that a key aspect of this definition, like others, is the consideration of a systemic approach defining this concept. Therefore, when studying the development, implementation, 
and effective functioning of the higher education management system, it becomes especially relevant to clarify the main theoretical, methodological, and practical foundations of the system approach.

In general terms, a systemic approach should be based on the study of a phenomenon and/or process, taking into account both the complexity of internal components and the environment of the existence and functioning of these processes and/or phenomena. Note that the main advantage of using the system approach is the comprehensive possibility of establishing links between elements of the complex of external and internal components. On this basis, one can form a judgment on the key general rules and principles of the existence of processes and/or phenomena within a certain holistic system.

The ability to identify systems and fully establish the theoretical and methodological foundations of their existence is based on the use of several concepts that allow you to meaningfully describe and analyze a certain system. Such concepts of the system structure include element, component, subsystem, supersystem; and those that reflect the basic and functional features of the structural parts of the system, namely, attribute, feature, property, etc. By an integral part of the system is usually meant a certain spatial, semantic, material, and functional insulation. But such insulation is conditional - this is a certain autonomy of the part in the composition (structure) of the system, which can be expressed in form, value, and functions of this part. Thus, in Figure 2, it is appropriate to highlight the relation of such components of the system as an element, component, subsystem, and supersystem regarding the higher education management system.

\section{FIGURE 1}

\section{MAIN COMPONENTS OF THE HIGHER EDUCATION MANAGEMENT SYSTEM AND THEIR RELATIONSHIP}

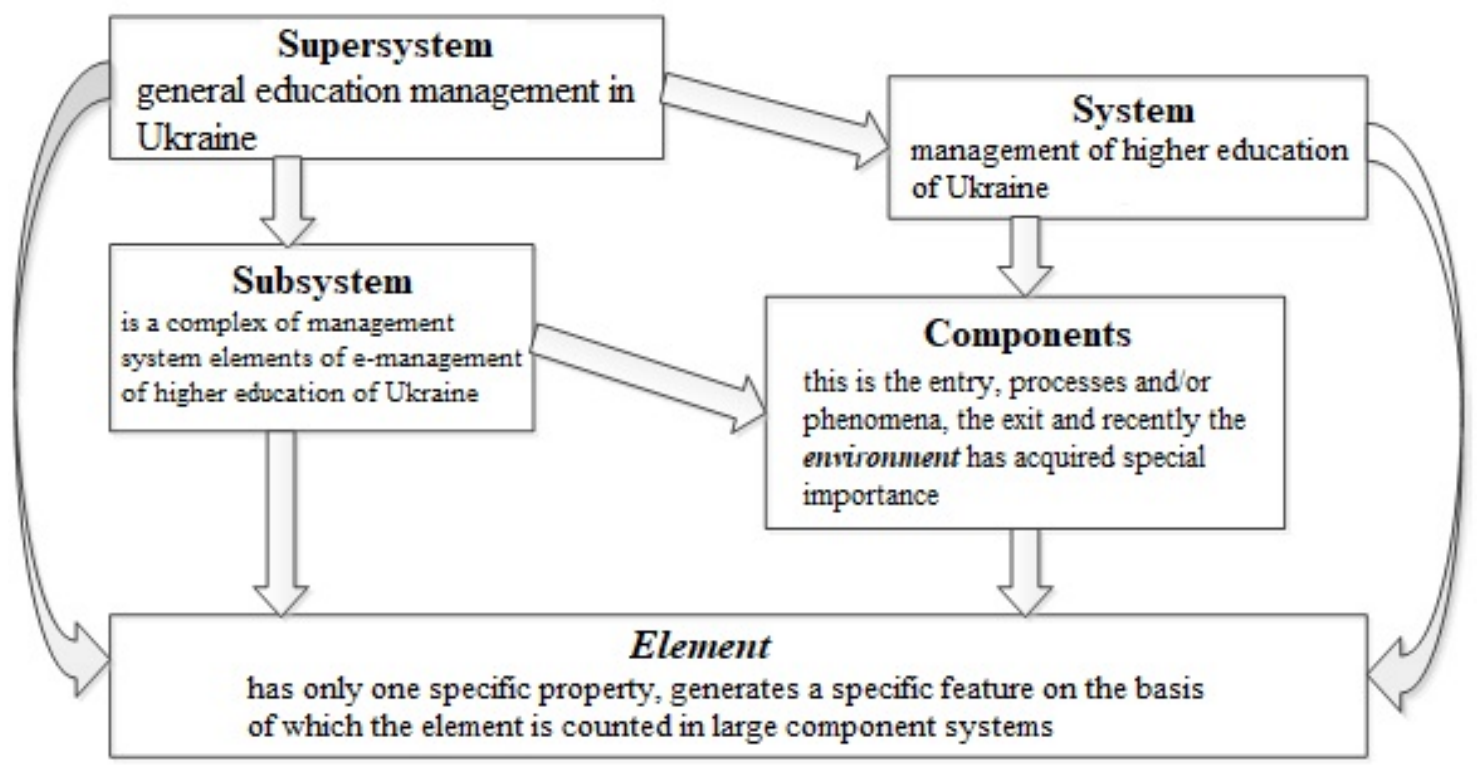

Figure 1 illustrates that the higher education management system is defined through its constituent parts. The correct understanding and use of the concepts of element, component, and subsystem should have a decisive influence on the process of system formation of higher education management. A reasonable and adequate clarification of the existing composition of components and subsystems will help to provide an opportunity to reduce the complexity of the creation and functioning of the system, which in the case of the higher education management system of Ukraine becomes relevant since its methodological approaches are only at the stage of formation. Thus, it can be concluded that the correct selection of elements, components, and subsystems is an independent important scientific task, the implementation of which depends on the formation of a general system for managing higher education in Ukraine. 
Based on the above study of the methodological foundations of system theory and system approach, Figure 2 shows the author's development of the higher education management system of Ukraine within the framework of strategic development, which includes all the best practices and practical achievements of well-known economists of state and public administration.

Figure 2 well illustrates that the entrance to the higher education management system of Ukraine should contain the identification of the goals and priorities of this process, as well as complete, reliable, and relevant retrospective information on the general state of higher education of Ukraine, taking into account internal and external challenges, threats, risks and hazards that directly and indirectly affect the entire system. Note that it is necessary to distinguish the essence of the categories of challenges, threats, risks and dangers. Therefore, we will use the following definitions of these concepts in the study.

\section{FIGURE 2 \\ UKRAINE'S HIGHER EDUCATION MANAGEMENT SYSTEM WITHIN THE FRAMEWORK OF STRATEGIC DEVELOPMENT}

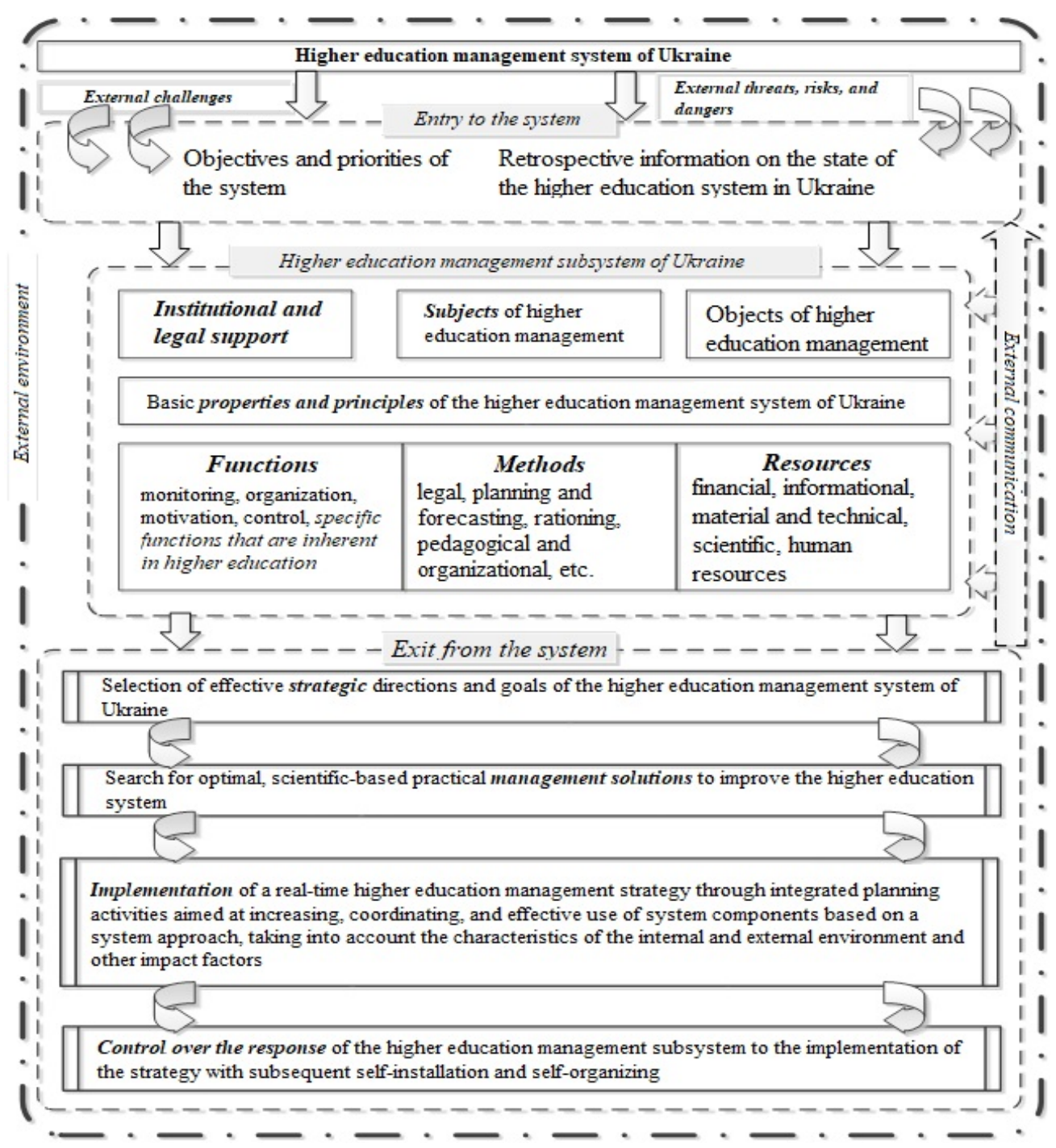




\section{FEATURES OF STRATEGIC DIRECTIONS OF HIGHER EDUCATION DEVELOPMENT IN UKRAINE: DESCRIPTION}

Challenges are a combination of some circumstances that do not necessarily have a negative impact, but require an adequate response, since ignoring them can have both positive and negative consequences for the entire management system. The threat is the impact of the external environment, its actors or internal elements of the system, which could potentially have negative consequences for the effective functioning of the management system. Risk is the possible occurrence of objective and/or subjective events in various segments of higher education due to the actualization of the threat, which can lead to both positive changes and negative consequences, and can also lead to deviation from the planned result. Danger is the main form of threat and risk, which leads to real negative consequences for the functioning of the entire system of higher education management. Among the main goals and priorities, which are the initial conditions for the effective functioning of the higher education management system of Ukraine, can be identified as:

- the introduction of sustainable innovative development of higher education in Ukraine through the training of highly qualified specialists, "production" and the providing of new knowledge and practical skills, as well as the formation of an intellectual and socio-spiritual outlook of society, ready for the challenges of the present and future;

- the formation of a competitive system of multi-directional higher educational institutions, which, through cooperation with the scientific and entrepreneurial sector, will form the special professional and scientific-educational potential of Ukrainian society on the basis of continuous professional and personal development;

- integration of higher education in Ukraine into the world educational and research space, etc.

Consider the main elements of the higher education management subsystem (Figure 3).

1. Institutional and legal support is an important element of the legislative and regulatory system for ensuring the quality of higher education at the state and municipal levels with the participation of national, social and professional organizations and institutions with the involvement of internal and if possible, external stakeholders to the development of new regulatory acts, methodological and institutional developments, which can guarantee the sustainable functioning and development of the system of ensuring the quality and effectiveness of higher education, introduction of legislation and regulations on a transparent system of admission to study, etc.

2. The subjects of management of the system are, on the one hand, state and municipal authorities, and, on the other, autonomous higher educational institutions of Ukraine in their decisions and development vectors.

3. The objects of the system management are training and education, the procedure for carrying out educational activities, the conditions for decision-making by the subjects of the educational services market, various administrative procedures in the field of higher education.

4. The main properties (general principles) of the higher education management system are clearly summarized in Figure 3. 


\section{FIGURE 3 \\ PROPERTIES (GENERAL PRINCIPLES) OF THE HIGHER EDUCATION MANAGEMENT SYSTEM OF UKRAINE}

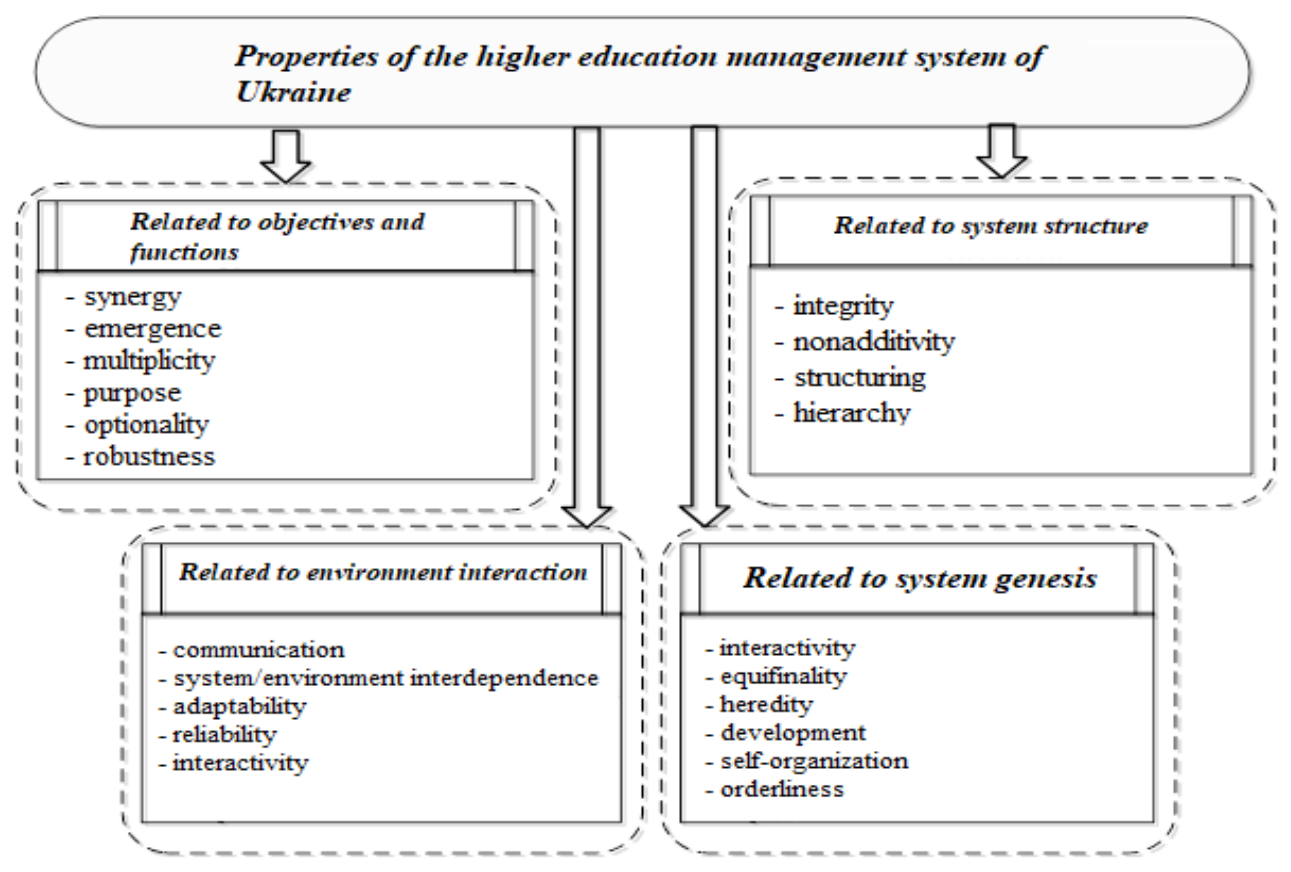

Among the main specific principles of the higher education management system are the following: university autonomy and institutional capacity of higher education institutions, transparency and openness of management, shared responsibility, feasibility, partnership, refusal to corruption, academic virtue, academic freedom, professionalism, focus on high scientific achievements, focus on achieving high quality education, focus on current and future priorities of society and national economy, preservation of heritage, preservation of intellectual human potential in fields, accessibility and equality, impartiality; orientation towards the comprehensive development of society and the individual; inclusiveness, external openness, adaptability, diversity, self-organization, sustainability, etc.

5. Among the main functions of the system, particular attention should be paid to monitoring, which is determined by a set of actions aimed at ensuring comprehensive management of the higher education management system, taking into account the variability and persistence of changes in the internal and external environment, as well as the effective selection of the best options from the overall through indicative and strategic planning.

The specific functions that are inherent in higher education are as follows:

- social recovery - reproduction of various aspects of social life and socio-professional structure;

- social displacement - changing the status of a person in society, with the opportunity to occupy a higher social status;

- the cultural and reproductive - impact of higher education on the preservation and enrichment of cultural heritage and values;

- communicative - is implemented through a two-level connection between education and the surrounding world;

- selective - is displayed in the natural differentiation of students by abilities, subject, and professional skills, etc; 
- social regulation and control - influence on the social self-awareness of educational applicants, the formation of conscious respectful attitude to state legal acts, values of society, etc;

- instrumental - development of ways and means of socialization of students, adaptation of young specialists to practical working conditions.

6. The methods of the system are a systematic set of possible tools with which you can fulfill the set goals and priorities at the entry and obtain the expected output results.

7. The following resources are the basis for the establishment of an effective higher education management system:

- financial resources are a complex of sources of formation and use of financial resources of educational institutions, necessary for their effective activity in order to provide educational services to consumers and to train specialists for the national economy in the conditions of the market of educational services;

- information resources are a complex of information sources, which are the basis of functioning reliability of the created system. Without complete, reliable, timely, differentiated, and potential information, an effective higher education system cannot be implemented;

- material and technical resources - all material means used to improve the quality of higher education by educational institutions;

- scientific resources make it possible to create and introduce new theoretical and practical knowledge within the framework of educational, methodological, and scientific work of higher educational institutions;

- human resources should consist of highly qualified teaching staff, with the desired practical experience and the ability to adapt applicants to the challenges of our time.

Thus, at the exit of the system developed in Figure 3, alternative options should be obtained for developing a higher education management strategy, in which the central link will be the search for optimal, scientific-based practical management solutions for the continuous improvement and selforganizing of the provided system.

It is proposed to introduce the following strategic directions for the development of the higher education management system of Ukraine (Table 1). The implementation of the presented strategic directions of the development of the higher education management system of Ukraine and the operational tasks of the managers for their implementation (Table 1) should be implemented in real-time with the help of comprehensive planned measures aimed at increasing, coordinating, and effective use of the system components based on a systemic approach taking into account the peculiarities of the internal and external environment and other factors of influence. 
TABLE 1

\section{STRATEGIC DIRECTIONS OF DEVELOPMENT OF THE HIGHER EDUCATION MANAGEMENT SYSTEM OF UKRAINE AND OPERATIONAL TASKS OF MANAGERS FOR THEIR IMPLEMENTATION}

\begin{tabular}{|l|l|l|}
\hline No. & \multicolumn{1}{|c|}{ Strategic directions } & \multicolumn{1}{c|}{ Operational tasks } \\
\hline 1 & $\begin{array}{l}\text { Continuous improvement of the } \\
\text { education management system and } \\
\text { provision of some autonomy to } \\
\text { higher education institutions }\end{array}$ & $\begin{array}{l}\text { - establishing a system of interaction between the state, } \\
\text { higher education institutions, and entrepreneurial } \\
\text { institutions; } \\
\text { - comprehensive development of the autonomy of higher } \\
\text { education institutions; } \\
\text { - balancing the interests of higher education institutions } \\
\text { with other entities of the system; } \\
\text { - financial independence of higher education institutions }\end{array}$ \\
\hline 2 & $\begin{array}{l}\text { Adjustment of offer and demand } \\
\text { balance in the labor market for } \\
\text { specialists with higher education }\end{array}$ & $\begin{array}{l}\text { - the establishment of an effective forecasting system for } \\
\text { labor market needs; } \\
\text { - development of a mechanism for cooperation between } \\
\text { higher education management entities in employment }\end{array}$ \\
\hline 3 & $\begin{array}{l}\text { Full accessibility of higher } \\
\text { education to the population, } \\
\text { regardless of their social status }\end{array}$ & $\begin{array}{l}\text { - formation of a transparent system of admission to } \\
\text { higher education institutions; } \\
\text { - ensuring that higher education is accessible and } \\
\text { inclusive to all segments of the population }\end{array}$ \\
\hline 4 & $\begin{array}{l}\text { Improving the quality of higher } \\
\text { education }\end{array}$ & $\begin{array}{l}\text { - use of innovative technologies and distance learning; } \\
\text { - material and technical support and modernization of the } \\
\text { laboratory base; }\end{array}$ \\
\hline 5 & $\begin{array}{l}\text { Raising the general and special level } \\
\text { of teaching in higher education } \\
\text { institutions }\end{array}$ & $\begin{array}{l}\text { - improving the social status of teachers in society; } \\
\text { - the system of stimulation of educational, } \\
\text { methodological, scientific, and organizational activities of } \\
\text { teachers, both financially and by other means (career } \\
\text { development, awards, etc.); }\end{array}$ \\
\hline $\begin{array}{l}\text { Integration into international } \\
\text { hervices and promotion of domestic }\end{array}$ & $\begin{array}{l}\text { - provision of a state program for the integration of higher } \\
\text { education institutions into European and international } \\
\text { educational services markets; } \\
\text { - internationalization of the educational process; } \\
\text { - attracting students from foreign countries to domestic } \\
\text { higher education institutions }\end{array}$ \\
\hline
\end{tabular}

The effective operation of the higher education management system of Ukraine should be monitored at all levels of the system, both by state and municipal authorities and by autonomous higher educational institutions. Only in this way the system will work reliably and deliver expected long-term results.

\section{CONCLUSIONS}

A study of the problems of the formation and functioning of the higher education management system of Ukraine, taking into account its strategic orientation was conducted in the article. The following theoretical, methodological, and practical results of the experiments were obtained, namely:

1. The relationship between the definition of "higher education" and the systemic approach was clarified, based on which it was concluded that in the study of the development, implementation, and effective functioning of the higher education management system, the use 
of modern and innovative methods and means, which are proposed by the system approach adapted to the needs of our research, becomes especially relevant.

2. Key research directions are identified within the framework of the system approach and it is proved that the main advantage in using this approach is the comprehensive possibility of establishing links between elements of the complex of external and internal components, with the help of which it is possible to form a judgment on key general rules and principles of the existence of processes and/or phenomena within a certain holistic system.

3. The components of the higher education management system are systematized and it is determined that the concepts of the system structure include: element, component, subsystem, supersystem; and those that reflect the basic and functional features of the structural parts of the system, namely, attribute, feature, property, etc.

4. The higher education management system in Ukraine within the framework of strategic development has been developed and its elements are described. The following conclusions and generalizations were made:

- entry into the higher education management system of Ukraine shall contain the objectives and priorities of this process, as well as complete, reliable, and relevant retrospective information on the general state of higher education of Ukraine, taking into account the conditions of internal and external challenges, threats, risks and dangers that directly and indirectly affect the entire system;

- among the main elements of the higher education management subsystem, it is appropriate to distinguish the following: institutional and legal support, subjects and objects, properties and principles, functions, methods, resources;

- at the exit of the system, alternative options should be obtained for the development of a higher education management strategy, in which the central link will be the search for optimal, scientific-based practical management solutions for the continuous improvement and self-organizing of the provided system.

5. Strategic directions for the development of the higher education management system of Ukraine and operational tasks of managers for their implementation were formed and it was concluded that their implementation should be implemented in real-time with the help of comprehensive planned measures aimed at increasing, coordinating, and effective use of system components based on system approaches, taking into account the characteristics of the internal and external environment and other factors of influence.

\section{REFERENCES}

Anikin, I.Y. (2020). The use of technological cycles in the management of an educational institution by integrating marketing technologies. International Journal of Learning and Change, 12(1), 25-43.

Da Costa, R.L., António, N.S., \& Dos Santos, J.B. (2019). Management consulting practices and praxis. International Journal of Learning and Change, 11(1), 39-56.

Diegtiar, O.A., Orlova, N.S., Kozureva, O.V., Shapovalova, A.M., \& Prykazka, S.I. (2019). Financial capacity of territorial communities: European experience and Ukrainian case. Collection of Scientific Works "Financial and Credit Activity: Problems of Theory and Practice", 4(31), 516526.

Dmytryshyn, M.V. (2013). A systematic approach to the formation of the financial mechanism of higher education. Scientific and Information Bulletin of Ivano-Frankivsk University of Law Named After King Danylo Halytsky, 8, 289-294.

Dziuba, T. (2021). Information model for improving accounting and analytical support for economic potential management. Scientific Horizons, 24(2), 108-119.

Hashim, M.S., Abdulhadi, A.M., \& Taher, M.J. (2021). Utilizing geographic information systems in pavement maintenance applications: Baghdad university as case study. Periodicals of Engineering and Natural Sciences, 9(1), 174-183. 
Holovii, L.V. (2013). Public administration of higher education in Ukraine. Scientific Bulletin of the National University of Life and Environmental Sciences of Ukraine, 182(3), 148-153.

Kachynska, N.F., Zemlyanska, O.V., Husiev, A.M., Demchuk, H.V., \& Kovtun, A.I. (2021). Labour protection as a component of effective management of a modern enterprise. Scientific Bulletin of Mukachevo State University. Series “Economics”, 8(1), 77-85.

Karabin, T.O. (2016). Distribution of powers of public administration (p.220). Uzhhorod: Hrazhda.

Klov, M.V. (2014). Institutional environment of the higher education system in the context of transformational social processes. Bulletin of the National Aviation University. Sociology. Politology. History: A Collection of Scientific Papers, 1, 17-21.

Kremen, V.H. (2008). Encyclopedia of education (p.1040). Kyiv: Yurinkom Inter.

Kushnir, I.I. (2020). Modern view on educational management. Scientific Bulletin of Mukachevo State University. Series "Pedagogy and Psychology", 1(11), 28-31.

Law of Ukraine "About higher education" dated July 1, 2014 No. 1556-VII. 2014. (n.d.). Retrieved from https://zakon.rada.gov.ua/laws/show/1556-18\#Text

Lelechenko, A.P., Diegtiar, O.A., Lebedinska, O.Y., Derun, T.M., \& Berdanova, O.V. (2020). Mechanisms of inter-state communications for solving sustainable development problems. Asia Life Sciences Supplement, 29(2), 1-9.

Luzik, E.V., Demchenko, N.I., Melnyk, N.I., Semichenko, V.A., \& Proskurka, N.M. (2021). Influence of tolerance to uncertainty on personal and professional development of pilots during aviation specialists' training. INCAS Bulletin, 13(Special Issue), 143-157.

National Agency for Quality Assurance in Education. (n.d.). Retrieved from https://naqa.gov.ua

Nepomnyashchyy, O. Medvedchuk, O., \& Lahunova, I. (2019). Legal regulation of conformity assessment of personnel qualification in construction. Asia Life Sciences, 21(2), 405-414.

Obolentsev, V.F. (2018). Basic principles of system analysis of the system of the state of Ukraine (p.98). Kharkiv: Pravo.

Oderii, L.P. (2011). Evaluation of international system education: Methodology and tools (p.196). Kyiv: ISDO.

Rezk, S.S., \& Gamal, S. (2020). An organizational cybernetics framework for designing a viable higher education system. Systemic Practice and Action Research, 33(6), 703-724.

Romanenko, Y. (2016). Place and role of communication in public policy. Problems of Economics, $176(2), 25-31$.

Strategies for the Development of Higher Education in Ukraine for 2021-2031.2020. (n.d.). Retrieved from https://mon.gov.ua/storage/app/media/rizne/2020/09/25/rozvitku-vishchoi-osviti-v-ukraini02-10-2020.pdf

Sych, T.V., Kryvtsova, O.M., Kaduk, N.I., Nesprava, M.V., \& Panchenko, G.O. (2021). Public administration in the education system: Theoretical and methodological approaches and practical recommendations. Journal of the National Academy of Legal Sciences of Ukraine, 28(2), 132 139.

Timashov, V.O., \& Kyrylenko, N.Ye. (2021). Development of e-government in Ukraine. Legal Horizons, $14(2), 38-43$.

Vakarchuk, I. (2008). Higher education in Ukraine - the European dimension: Status, problems, prospects. High School, 3, 3-18.

Voloshchuk, R.V. (2013). Comparative analysis of approaches to determining the weights of integrated indices of complex systems. Inductive Modeling of Complex Systems, 5, 151-165.

Yashchuk, T.A. (2017). Higher education system in Ukraine and funding. Global and National Economic Problems, 17, 784-787.

Yashchuk, T.A., \& Chyrva, O.H. (2018). Directions for improving the mechanism of financial support for the activities of higher education institutions. Economic Bulletin of the Zaporizhzhia State Engineering Academy, 5(17), 45-50. 